\title{
Tumor Replacement
}

National Cancer Institute

\section{Source}

National Cancer Institute. Tumor Replacement. NCI Thesaurus. Code C54692.

The process whereby normal tissue cells and structures are replaced by tumor cells. 